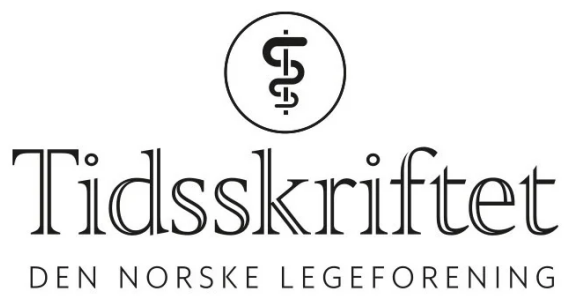

\title{
Krig i Europa
}

\section{REDAKSJONELL KOMMENTAR}

\section{RAGNHILD $\varnothing R S T A V I K$}

ragnhild.orstavik@tidsskriftet.no

Ragnhild Ørstavik er assisterende sjefredaktør i Tidsskriftet. Hun er dr.med. og har en bistilling som forsker ved Folkehelseinstituttet.

\section{En krig er også en helsekrise.}

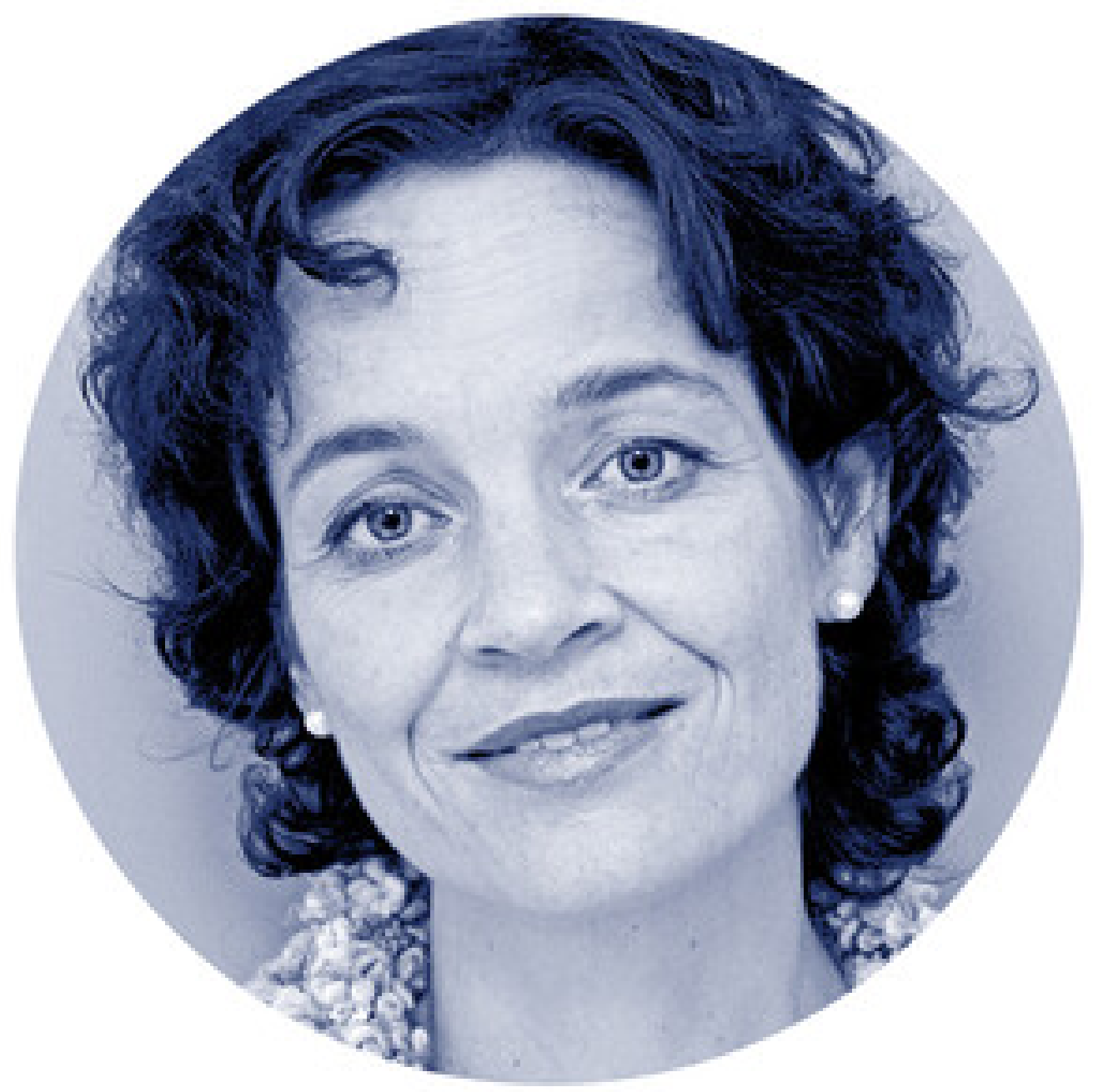

Foto: Einar Nilsen 
For ikke lenge siden så jeg filmen They shall not grow old, en restaurert og fargelagt dokumentarfilm fra første verdenskrig (1). Effekten var slående. De livlige, unge mennene kom rett inn i stuen min. Det kunne vært nå. Det kunne vært her. Og nå er det nå, og nesten her: Krigen i Ukraina minner oss om at krig ikke bare er et annet sted, i en annen tid. Og det er tid også for å minne hverandre om at krig er en helsekrise (므).

FNs generalsekretær advarte allerede forrige torsdag om en kommende helsekrise i Ukraina (3). Tre dager senere gisper sykehusene etter luft - de mangler oksygen til kritisk syke pasienter, blant dem 1700 med covid-19 (4). Hvis konflikten fortsetter, er dette bare begynnelsen. For i vår tid går krig mest ut over dem som ikke kriger. I første verdenskrig var én av syv drepte sivile, i andre var det to av tre, og på slutten av det forrige århundret utgjorde sivile inntil 9o \% av de drepte i væpnede konflikter (5). I tillegg kommer de indirekte effektene, der man svært grovt anslår at for hver person som dør av skader, er det ni til som dør av andre årsaker (2,.5). Krig fører til mer infeksjoner, økt barsel- og barnedødelighet, flere seksuelt overførbare sykdommer, avbrutte vaksinasjonsprogrammer og sult - for å nevne noe (5). Krig fører også til endring i helseatferd og økning av ikke-smittsomme sykdommer og har fatale konsekvenser for psykisk helse $(\underline{2}, 5)$.

Rundt to milliarder av jordens befolkning befinner seg allerede i konfliktrammede og ustabile områder, hvorav rundt 70 millioner er på flukt (5). Invasjonen i Ukraina må stoppes, så det ikke blir enda flere.

Har du synspunkter på krisen eller erfaringer fra felt? Tidsskriftet hører gjerne fra deg. Ring oss eller send en henvendelse til redaksjonen@tidsskriftet.no.

Vil du høre hvordan det er å jobbe som lege i konfliktrammede områder? Lytt til vår podkast fra 2020, der Kari Schrøder Hansen forteller om sine opplevelser.

\section{REFERENCES}

1. Jackson P. They Shall Not Grow Old. Dokumentarfilm. London: Warner Bros, 2018.

2. Sheather J. As Russian troops cross into Ukraine, we need to remind ourselves of the impact of war on health. BMJ 2022; 376: 0499. [PubMed][CrossRef]

3. Verdens helseorganisasjon. WHO Director-General: Deeply concerned over escalating health crisis in Ukraine. https://www.who.int/news/item/24-02-2022-who-director-general-deeply-concerned-overescalating-health-crisis-in-ukraine Lest 28.2.2022.

4. Verdens helseorganisasjon. Dangerously low medical oxygen supplies in Ukraine due to crisis, warn WHO Director-General and WHO Regional Director for Europe.

https://www.who.int/news/item/27-02-2022-dangerously-low-medical-oxygen-supplies-in-ukraine-dueto-crisis-warn-who-director-general-and-who-regional-director-for-europe Lest 28.2.2022.

5. Garry S, Checchi F. Armed conflict and public health: into the 21st century. J Public Health (Oxf) 2020; 42: e287-98. [PubMed][CrossRef]

Publisert: 1. mars 2022. Tidsskr Nor Legeforen. DOI:10.4045/tidsskr.22.0179

(C) Tidsskrift for Den norske legeforening 2023. Lastet ned fra tidsskriftet.no 26. april 2023. 